\title{
Enhanced Cellular Cryopreservation by Biopolymer-Associated Suppression of RhoA/ROCK Signaling Pathway
}

\author{
Tae Wook Lee ${ }^{1,+}$, Gyeong Won Lee ${ }^{1,+}$, Seonyeong An ${ }^{1}$, Keum-Yong Seong ${ }^{1}$, Jong Soo Lee ${ }^{2,3, *}$ \\ and Seung Yun Yang ${ }^{1, *}$ \\ 1 Department of Biomaterials Science (BK21 Four Program), Life and Industry Convergence Institute, \\ Pusan National University, Miryang 50463, Korea; notea007@naver.com (T.W.L.); \\ 22jungbi@gmail.com (G.W.L.); seonyeong510@gmail.com (S.A.); ky.seong0124@gmail.com (K.-Y.S.) \\ 2 Department of Ophthalmology, College of Medicine, Pusan National University, Busan 49241, Korea \\ 3 Medical Research Institute, Pusan National University Hospital, Busan 49241, Korea \\ * Correspondence: jongsool@pusan.ac.kr (J.S.L.); syang@pusan.ac.kr (S.Y.Y.) \\ + Authors contributed equally to this work.
}

Citation: Lee, T.W.; Lee, G.W.; An, S.; Seong, K.-Y.; Lee, J.S.; Yang, S.Y. Enhanced Cellular Cryopreservation by Biopolymer-Associated Suppression of RhoA/ROCK Signaling Pathway. Materials 2021, 14 6056. https://doi.org/10.3390/ ma14206056

Academic Editors: Halina Kaczmarek and Giovanni Vozzi

Received: 2 September 2021

Accepted: 9 October 2021

Published: 14 October 2021

Publisher's Note: MDPI stays neutral with regard to jurisdictional claims in published maps and institutional affiliations.

Copyright: (c) 2021 by the authors. Licensee MDPI, Basel, Switzerland. This article is an open access article distributed under the terms and conditions of the Creative Commons Attribution (CC BY) license (https:// creativecommons.org/licenses/by/ $4.0 /)$.

\begin{abstract}
With increasing demands on long-term storage of cells, cryopreservation of cells is gaining more importance in cell-based research and applications. Dimethyl sulfoxide (DMSO) is a commonly used chemical cryoprotectant, providing increased cell survival during the freezing process. However, its use is limited in clinical applications due to its low biocompatibility above cryogenic temperatures. Herein, we present a new approach for reducing the use of DMSO in cryopreservation by using biodegradable hyaluronic acids (HAs). By adding HAs into cryoprotectant media containing a low concentration of DMSO, higher cell viability and cell proliferation rate were observed upon thawing after cryopreservation. The HA-supplemented cryopreservation media did not reduce the size of the ice crystal, which significantly influenced cell viability during cell freezing, but decreased the Ras homolog family member A (RhoA)/Rho-associated protein kinase (ROCK) signaling pathway related to apoptosis. The cell-interactive cryoprotectants containing HA can be applied to the development of a new cryoprotectant that reduces the adverse effect of DMSO.
\end{abstract}

Keywords: cryopreservation; hyaluronic acid; dimethyl sulfoxide (DMSO); RhoA/ROCK signaling pathway; polymeric cryoprotectant

\section{Introduction}

The importance of cell cryopreservation is emerging because of the development of various fields that use whole cells, including cell therapy [1-4], regenerative medicine [5-7], stem cell research [8], and organ transplantation [9-11]. For these cell-based applications, it is necessary to provide a sufficient number of cells and to ensure their activity and stability. Due to cost-related issues and the reduced cell activity during cell maintenance, cryopreservation of cells has been used for the long-term storage of living cells. Cells retain their biological properties even after freezing, and the functions of cells can also be recovered after being thawed [12].

Cryoprotectants are widely used to prevent freezing damage to biological tissues. Since the use of glycerol as a cryoprotectant was first reported in 1949 [13], various cryoprotectants have been used in cryobiology for the cryopreservation of blood cells and bull sperm. Generally, the cryoprotectant enters the cytoplasm, creating an osmotic gradient, which in turn promotes intracellular water efflux, converts the cytoplasm to an amorphous state, and lowers the temperature at which ice begins to form. It also protects cells from freezing by inducing attenuation of osmotic damage due to electrolyte concentration and stabilization of membranes and intracellular structures [14]. Dimethyl sulfoxide (DMSO) is the most commonly used cryoprotectant for the preservation of cells or tissues [15] because it inhibits the formation of ice crystals, which constitute the major physical stress associated 
with cell cryopreservation [16]. However, due to the toxicity of DMSO, cryopreservation with DMSO could negatively affect cells and tissues and lead to post-transplant complications $[17,18]$. Thus, it is necessary to develop new cryoprotectants to reduce the use of DMSO in cryopreservation procedures.

Currently, many research efforts have been devoted to developing a novel cryopreservation method that can replace DMSO $[19,20]$. Inspired by the survival of organisms living in subzero environments, antifreeze proteins (AFPs), found in polar marine organisms, have received great attention as a cryoprotectant [21-23]. AFPs inhibit ice recrystallization or allow ice crystals to form in a unique shape, thereby inhibiting cell damage during freezing. However, since AFP shows variable cryopreservation performance depending on the cell type and AFP concentration, it is difficult to establish a standard protocol [24]. In addition, the synthesis process of AFPs, requiring multiple purification steps, is unfavorable for cost-effective production.

Alternatively, synthetic polymers such as polyvinyl alcohol (PVA) have the advantage of being able to mimic the function of AFPs by designing them to inhibit the formation of ice crystals and the advantage of being produced cheaply in large quantities [25]. Although synthetic, non-biodegradable polymer-based cryoprotectants were effective in reducing the size of ice crystals, their residues could potentially lead to less biocompatibility in vivo environments [26]. Recently, biodegradable polymeric cryoprotectants have gained special interest as cryoprotectants due to their complete enzymatic degradation in vivo and excellent biocompatibility [5,11,27-29]. Natural biopolymers can induce the release of various growth factors through cell interaction to maintain tissue regulation and homeostasis. The activity of these growth factors can affect systemic or cellular signaling [30].

Recent research demonstrated enhanced cellular cryopreservation by regulating cell signaling [31,32]. For instance, Tian et al. exhibited an increased cryopreservation effect by controlling the RhoA / ROCK1 signal, which increases apoptosis by regulating phosphorylation of the myosin light chain in apoptotic cell [31-33]. However, there is still insufficient evidence that biopolymers can increase the cryopreservation effect by regulating apoptosis through the RhoA/ROCK1 signal pathway.

Among various biopolymers, hyaluronic acid (HA), a ubiquitous component of the extracellular matrix in soft tissues, is a good candidate as a cryoprotectant because of its nontoxicity, biodegradability, and large-scale production [28,34]. The HA used for cryopreservation improved cell viability during cell freezing [35-37] and showed increased activity of human spermatozoa after exposure to HA [38]. Additionally, when HA-supplemented cryoprotectant was used in human stem cells, the morphology and adhesion of the cells improved [39]. However, despite extensive evidence suggesting the benefits of HA for cryopreservation, the underlying mechanisms remain unclear.

In this study, we aimed to develop a biodegradable polymeric cryoprotectant for reducing the effect of DMSO on cells during cryopreservation. We chose HA as a biodegradable cryoprotectant and examined its effect on cell cryopreservation. In addition, we investigated the cellular signaling pathways induced by polymeric supplements during cryopreservation to reveal potential mechanisms related to HA.

\section{Materials and Methods}

\subsection{Materials}

Murine NIH-3T3 fibroblasts were purchased from ATCC (Manassas, VA, USA). Dulbecco's modified Eagle's medium with high glucose (DMEM, DMEM-HPA), fetal bovine serum (FBS, SH30910.03), and penicillin-streptomycin (SV30010) were purchased from Hyclone (Logan, UT, USA). DMSO (DR1022-500-00) and radioimmuno-precipitation assay (RIPA, RC2002-050-00) buffer was purchased from Biosesang (Sungnam, Korea). PVA (weight average molecular weight $\left(\mathrm{M}_{\mathrm{W}}\right): 8000 \mathrm{~g} / \mathrm{mol}, 360627$ ), thiazolyl blue tetrazolium bromide (MTT, M5655), protease (P4630), phosphatase inhibitors (P5726), and Ponceau S solution (P7170) were purchased from Sigma-Aldrich (St. Louis, MO, USA). Cryofreezing container (5100-0001) and trypan blue (15250061) were purchased from Thermo Fisher 
Scientific (Waltham, MA, USA). HelixCriptTM 1st-Strand cDNA Synthesis Kit (CDNA50) was purchased from Nanohelix (Daejeon, Korea). HAs with different $\mathrm{M}_{\mathrm{W}}(5000 \mathrm{~g} / \mathrm{mol}$ referred as oligo-HA and 100,000 g/mol referred as HA) were purchased from SNvia (Busan, Korea). Sodium dodecyl sulfate-polyacrylamide gel (1610302) and nitrocellulose membranes (1703202) were purchased from Bio-Rad (Hercules, CA, USA). Ez-Western LuMiLa kit (DG-WD100) was purchased from DogenBio (Seoul, Korea). RhoA (\#2117, 21 $\mathrm{kDa})$, ROCK1 (\#4035, $160 \mathrm{kDa})$, and GAPDH (\#2118, $37 \mathrm{kDa}$ ) antibody were purchased from Cell Signaling Technology. Goat anti-rabbit IgG, polyclonal antibody (ADI-SAB-300-J) was purchased from Enzo Life Sciences.

\subsection{Cell Culture}

Murine NIH-3T3 fibroblasts were cultured in a $25 \mathrm{~cm}^{2}$ culture dish using DMEM supplemented with $10 \%$ FBS and penicillin-streptomycin $(100 \mathrm{UI} / \mathrm{mL})$. Cultures were maintained at $37{ }^{\circ} \mathrm{C}$ in a sterile incubator (Labogene, Seoul, Korea) at $5 \% \mathrm{CO}_{2}$ until confluence was reached prior to cryopreservation.

\subsection{Cryopreservation}

To prepare cryopreservation media, polymers (PVA, HA, or oligo-HA) were added to DMSO cryoprotective solutions (DMSO 2.5\%, FBS 50\%, and DMEM 47.5\%) with different polymer concentrations; PVA, HA, and Oligo-HA: 1, 5, 10, and $20 \mathrm{mg} / \mathrm{mL}$ or polymer free (control). Murine NIH-3T3 fibroblasts $\left(1 \times 10^{6}\right.$ cells) were diluted at $25{ }^{\circ} \mathrm{C}$ with cryoprotective solution alone (control) or supplemented with different concentrations of polymer. The samples were transferred to isopropanol-filled cryofreezing containers, cooled down to $-80^{\circ} \mathrm{C}$ in a low-temperature freezer, and stored at least for $24 \mathrm{~h}$ before evaluation. The samples were thawed in water bath at $37^{\circ} \mathrm{C}$ for $30 \mathrm{~s}$. An amount of $1 \mathrm{~mL}$ sample was diluted in $9 \mathrm{~mL}$ culture medium and centrifuged at $300 \times \mathrm{g}$. After removing the supernatant and collecting the cell pellet, dead cells were counted using trypan blue solution.

\subsection{Trypan Blue Exclusion Assay}

After thawing the frozen NIH-3T3 cells, they were transferred to culture medium and centrifuged at $350 \times g$ to collect the cells. Collected cells were stained with $0.4 \%$ trypan blue, and viable cells were counted by hemocytometry. Images of stained viable cells were captured using an optical microscope (Nikon, Eclipse TS2, Tokyo, Japan) coupled with digital camera (i-Solution IMT, BC, Canada). Cells not stained with trypan blue were counted as live cells, and stained cells were counted as dead cells.

\subsection{MTT Assay}

The proliferation of NIH-3T3 cells was assessed using the MTT assay. Typically, the culture medium in the 24-well plate was completely replaced with $500 \mu \mathrm{L}$ of DMEM containing $10 \%(v / v)$ MTT solution, and the plate was placed in an incubator at $37^{\circ} \mathrm{C}$ for $1.5 \mathrm{~h}$. Formazan quantification was performed with standard graphs containing 0 to $2 \times 10^{5}$ cells. All the parameters were recorded under similar experimental conditions. Formazan in the cells was dissolved in $200 \mu \mathrm{L}$ of DMSO. DMSO $(100 \mu \mathrm{L})$ was transferred into a flat-bottomed 96-well plate, and the fluorescence intensity at $570 \mathrm{~nm}$ was measured using a microplate reader (Allsheng, Hangzhou, China).

\subsection{Splat Assay}

The size of the ice crystals was measured using a splat assay [21]. An amount of $10 \mu \mathrm{L}$ of cryopreservation media containing polymeric supplements was dropped from a height of $1.4 \mathrm{~m}$ through a $10 \mathrm{~cm}$ diameter tube onto a polished aluminum (Al) block cooled with liquid nitrogen. The ice wafer $(\sim 1 \mathrm{~cm})$ formed on the Al block was transferred to a precooled glass slide and then moved to a freezing stage connected to a temperature controller (LTS120; Linkam, Epsom Downs, UK) that had been equilibrated at $-20{ }^{\circ} \mathrm{C}$. The 
stage temperature was increased to $-8^{\circ} \mathrm{C}$ at a rate of $1^{\circ} \mathrm{C} / \mathrm{min}$, and the wafer was then left to anneal for $30 \mathrm{~min}$ at $-8{ }^{\circ} \mathrm{C}$. The temperature was maintained during ice crystal measurement. The ice crystals were visualized using a microscope (DM2700M, Leica, Wetzlar, German) with crossed polarizing filters.

\subsection{Quantitative Real-Time PCR Analysis}

Comparative Ras homolog family member A (RhoA) and Rho-associated protein kinase 1 (ROCK1) gene expression was accomplished in five groups of NIH-3T3 cells, and each group was harvested after treatment with the specific polymer for $30 \mathrm{~min}$. For each group of NIH-3T3 cells, total RNA was extracted using Trisure reagent. Reverse transcription reactions were performed using the HelixCript ${ }^{\mathrm{TM}} 1$ st-Strand cDNA Synthesis Kit. All water used for qPCR was DNase and RNase-free water. In addition, cDNA was synthesized using the RNase inhibitor included in the HelixCriptTM 1st-Strand cDNA Synthesis Kit. The extracted RNA was evaluated using Nanodrop (Nano-400; Allsheng, Hangzhou, China), and all RNA used in experiments had a purity (A260/A280) value of 1.8 or higher. Real-time polymerase chain reaction (RT-PCR) was performed using the StepOnePlus Real-Time PCR System (Thermo Fisher Scientific). For each real-time qPCR reaction, triplication in three independent trials was performed in a $20 \mu \mathrm{L}$ system, including $10 \mu \mathrm{L} 2 \times$ SYBR Green Realtime PCR master mix (Toyobo Co. LTD, QPK-201), $1 \mu \mathrm{L}$ of $10 \mathrm{pM}$ reverse primer and forward primer, $100 \mathrm{ng}$ template $\mathrm{cDNA}$, and sterile $\mathrm{ddH}_{2} \mathrm{O}$. The analysis process of qPCR reacting included $30 \mathrm{~s}$ at $95^{\circ} \mathrm{C}, 40$ cycles of $5 \mathrm{~s}$ at $95^{\circ} \mathrm{C}$, followed by $30 \mathrm{~s}$ at $60{ }^{\circ} \mathrm{C}$, and finally at $60^{\circ} \mathrm{C}$ extension for $10 \mathrm{~min}$. All primer sequences were checked with Primer-BLAST, all samples were tested using melting curve analysis, and all experiments contained no-template control without any amplification of specific PCR products. The following mouse RhoA and ROCK1 gene-specific primers were used for real-time amplification: mouse RhoA, forward 5'-CCG TCG GTT CTC TCC ATA GC-3' and reverse 5'-TCT CAG ATG CAA GGC TCA AGG-3'; and mouse ROCK1, forward 5'-AAG CTT TTG GCA ATC AGC- $3^{\prime}$ and reverse $5^{\prime}$-TTC TGT AAA CTT TCC TGC AAG C-3'. Mouse glyceraldehyde 3-phosphate dehydrogenase (GAPDH) was chosen as the housekeeping gene and amplified with the following primers: forward $5^{\prime}$-CGA CTT CAA CAG CAA CTC CCA CTC TTC C-3' and reverse 5'-TGG GTG GTC CAG GGT TTC TTA CTC CTT-3'. Samples were run in triplicate, and the relative gene expression was calculated using the comparative threshold cycle and normalized to the expression of GAPDH $(\Delta \mathrm{C} t)$. Results are expressed as fold-changes relative to the mean. The results of qPCR were analyzed by the software (StepOne software v.2.2.2, Applied Biosystems, Waltham, MA, USA) of StepOnePlus Real-Time PCR System, three independent trials were performed, and the outliers among the triplication results were removed and averaged. The specificity of each gene was confirmed through the melting curve of the qPCR results, the amplification efficiency of qPCR was close to 1, and no-template control was not detected in 40 cycles or less. The threshold value of each gene was applied automatically by the qPCR program. The significance of each result was determined by $t$-test.

\subsection{Western Blotting}

NIH-3T3 cells were treated with each polymer for $30 \mathrm{~min}$, PVA $(10 \mathrm{mg} / \mathrm{mL}), \mathrm{HA}$ $(10 \mathrm{mg} / \mathrm{mL})$, and oligo-HA $(10 \mathrm{mg} / \mathrm{mL})$. Cells were washed twice with phosphate-buffered saline (PBS) and then lysed in RIPA buffer with protease and phosphatase inhibitors. The cell lysates were centrifuged for $15 \mathrm{~min}$ at $4{ }^{\circ} \mathrm{C}$, and the supernatants were used for Western blotting. The cell lysate was loaded onto a sodium dodecyl sulfate-polyacrylamide gel at $10 \mu \mathrm{g}$ each and lysed by electrophoresis, transferred onto nitrocellulose membranes, and stained with $0.1 \%$ Ponceau $S$ solution to ensure equal loading of the samples. After blocking with 5\% non-fat milk for $30 \mathrm{~min}$, the membranes were incubated with primary antibodies overnight and were incubated for $2 \mathrm{~h}$ at $25^{\circ} \mathrm{C}$ with secondary antibody diluted 1:5000, and the bound antibodies were incubated with horseradish peroxidase-conjugated secondary antibodies using the Ez-Western LuMiLa kit. Protein bands were visualized 
using ChemiDoc (Bio-Rad). To quantify the Western blot results, the relative level of the target proteins was normalized to GAPDH. The band intensities were determined using ImageJ software (NIH, Bethesda, MD, USA).

\subsection{Statistical Analysis}

Results of multiple observations are presented as the mean \pm standard deviation (SD). For analysis of multivariate data, group differences were assessed using one-way or two-way analysis of variance (ANOVA), followed by Scheffe's post hoc test.

\section{Results and Discussion}

\subsection{Effect of Polymeric Supplements on Cell Cryopreservation}

To assess the effect of polymeric supplements on cell cryopreservation, cell viability tests were performed using mouse NIH-3T3 cells after freezing in media containing $2.5 \mathrm{wt} \%$ DMSO and the tested polymers. To minimize potential side effects, DMSO should be removed before cells are infused into patients. Although DMSO showed concentrationdependent in vitro cytotoxicity in the normal culture condition, culture media containing $2.5 \mathrm{wt} \%$ DMSO exhibited relatively good cell viability (Figure S1). We used PVA (Mw: $8000 \mathrm{~g} / \mathrm{mol}$ ) and HA (Mw: 100,000 g/mol and $5000 \mathrm{~g} / \mathrm{mol}$ ) as a supplement to DMSO. PVA has been widely used as an effective polymeric cryoprotectant, mainly through its effect of inhibiting ice recrystallization [40]. Due to hydrophilic moieties of the polymer chain, they exhibited good water solubility up to $20 \mathrm{mg} / \mathrm{mL}$. The freezing media supplemented by HA with different molecular weights (referred to as HA and oligo-HA) showed increased viability of NIH-3T3 cells during cryopreservation. Especially, high molecular weight $\mathrm{HA}$ at the concentrations of $10 \mathrm{mg} / \mathrm{mL}$ showed post-thaw recoveries of up to $90 \%$ compared with 37\% using DMSO-only cryopreservation (Figure 1a). In contrast, when PVA was added in the cryopreservation media, cell viability was reduced following the cryopreservation of cells (less than $10 \%$ post-thaw recovery). As the cryopreservation effect of PVA can be affected by the concentration and molecular weight, the decreased cell viability in PVA-supplemented cryopreservation media might be improved by using ultralow dispersity PVA with proper molecular weight [41]. It was found that $2.5 \%$ DMSO cryopreservation media supplemented with HAs showed similar cell viability as the group cryopreserved with standard DMSO cryoprotective solutions (7.5\% DMSO) (Figure S2).

To evaluate cell proliferation after cryopreservation, we cultured frozen cells after thawing and measured the growth rate of the cells using the MTT assay. We confirmed that cells treated with HA $(10 \mathrm{mg} / \mathrm{mL})$ and oligo-HA (5 or $10 \mathrm{mg} / \mathrm{mL}$ ) showed normal cell growth after the cryopreservation process. However, the addition of more than $20 \mathrm{mg} / \mathrm{mL}$ of HA or oligo-HA to the cryopreservation media inhibited cell growth (Figure 1b). The high concentrations of HA may have induced a cytotoxic effect upon cell freezing by causing damage to the CD44 receptor [42-44]. Additionally, we performed cell viability tests using human adipose-derived mesenchymal stem cells and rabbit corneal stromal cells to confirm the cryopreservation effect of HA-supplemented freezing media. Similar to the results obtained with NIH-3T3 cells, it was confirmed that both cells exhibited high cell viability when HA-supplemented freezing media were used (Figure S3).

\subsection{Ice Recrystallization Inhibition Activity of Polymeric Supplements}

Since ice recrystallization can cause mechanical damage during cell cryopreservation, the inhibition of this process is necessary [45-47]. To evaluate the ice recrystallization inhibition (IRI) activity of polymeric supplements, we measured the size of ice crystals through a splat assay, illustrated in Figure $2 \mathrm{a}$. A small amount $(10 \mu \mathrm{L})$ of cryoprotectant-contained solution was dropped onto an aluminum block chilled by liquid nitrogen and annealed at $-8{ }^{\circ} \mathrm{C}$ for ice crystallization before measuring the size of ice grains using a polarizing microscope [21]. The average diameter was defined as half of (width (W) + length (L)) of an ice grain as shown in the inset of Figure $2 b$. The PVA-supplemented freezing medium (less than $1 \mu \mathrm{m})$ reduced the size of ice crystals compared with the DMSO only group $(19.7 \pm 4.2 \mu \mathrm{m})$ 
(Figure $2 b, c)$. This IRI activity of PVA is attributed to the weak and reversible adsorption of PVA on the ice surface [21]. In contrast, the freezing media supplemented with HAs (HA and oligo-HA groups) showed similar ice crystal sizes to those of the DMSO group. Given the enhanced cell cryopreservation in HA-supplemented freezing media (Figure 1a), this result suggests that the addition of HA to the freezing media has another function of increasing cellular cryopreservation rather than inhibiting ice formation and growth, which is the working mechanism of common polymeric cryoprotectants such as PVA.

(a)

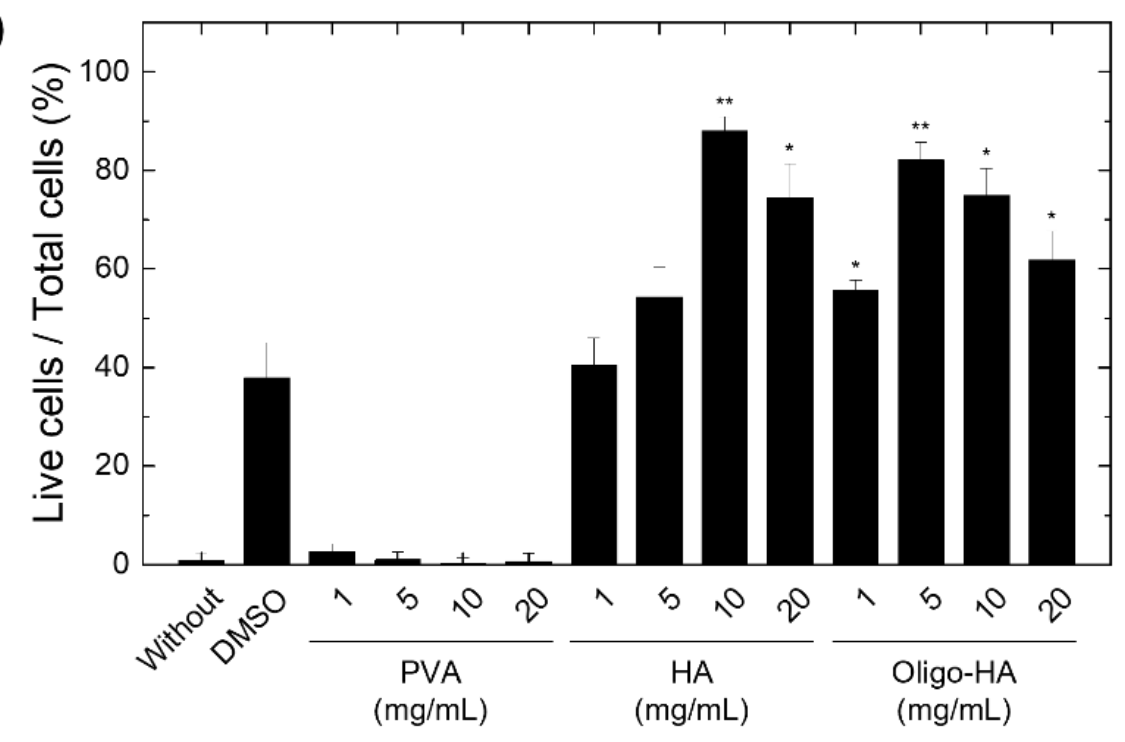

(b)

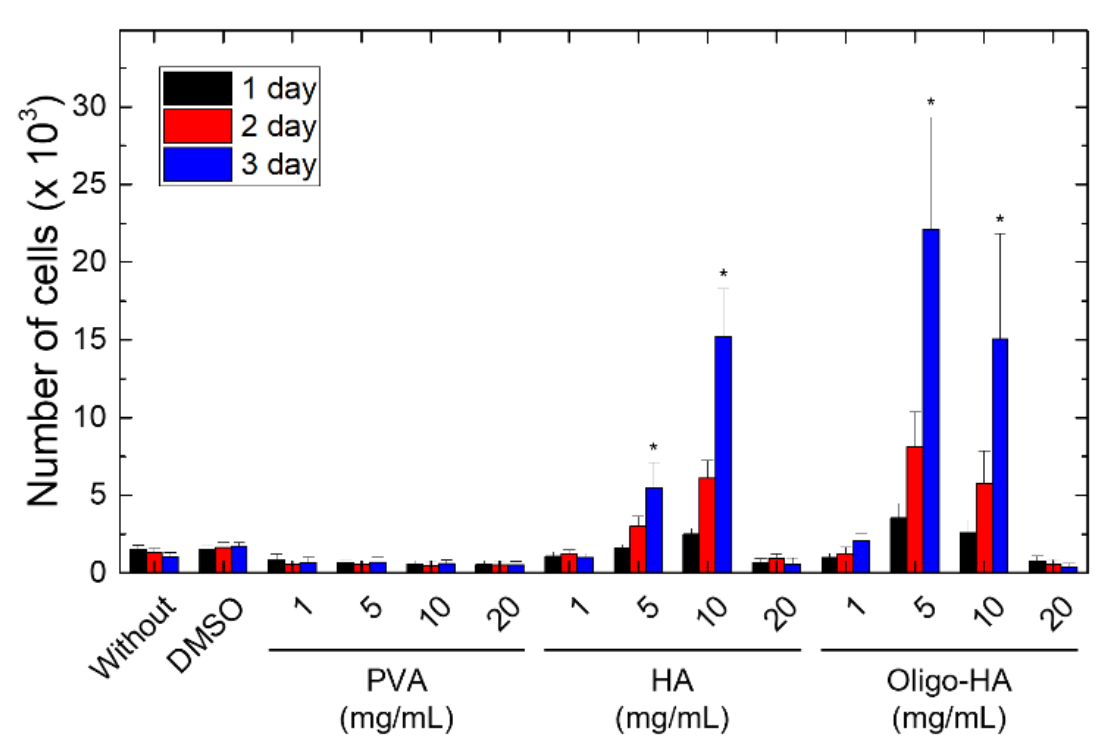

Figure 1. Effect of polymeric supplements on cell cryopreservation. (a) The bar graph shows the ratio of living cells per total cells. Polyvinyl alcohol (PVA) and hyaluronic acids (HA) with different concentrations were supplemented to dimethyl sulfoxide (DMSO) cryopreservation media. Dulbecco's modified Eagle's medium (DMEM) media without DMSO (without group) was used as a control. (b) The graph shows cell proliferation for $3 \mathrm{~d}$ after cell thawing. The data represent the mean \pm S.D. ${ }^{*} p<0.05$ and ${ }^{* *} p<0.01$ vs. DMSO. $(\mathrm{n}=5)$. 
(a)

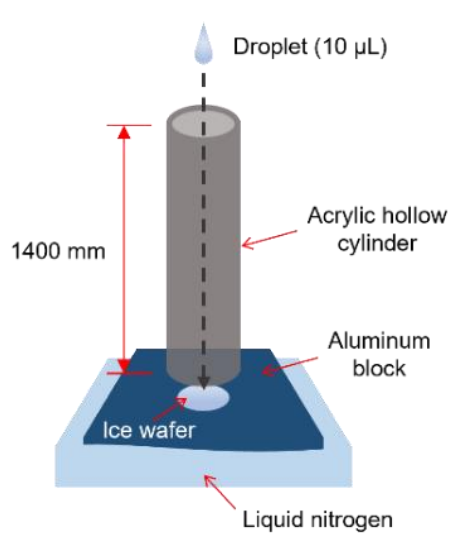

(c)

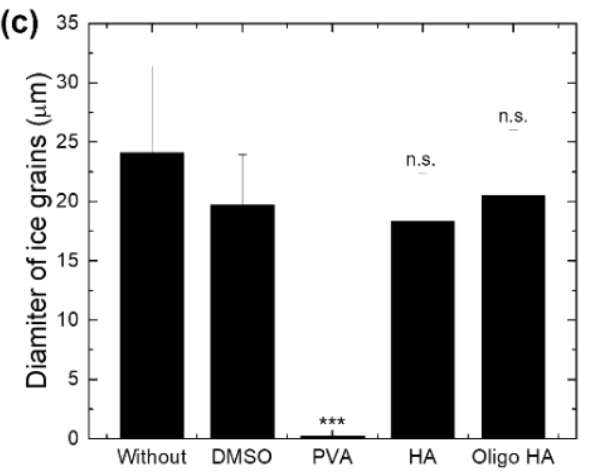

(b)
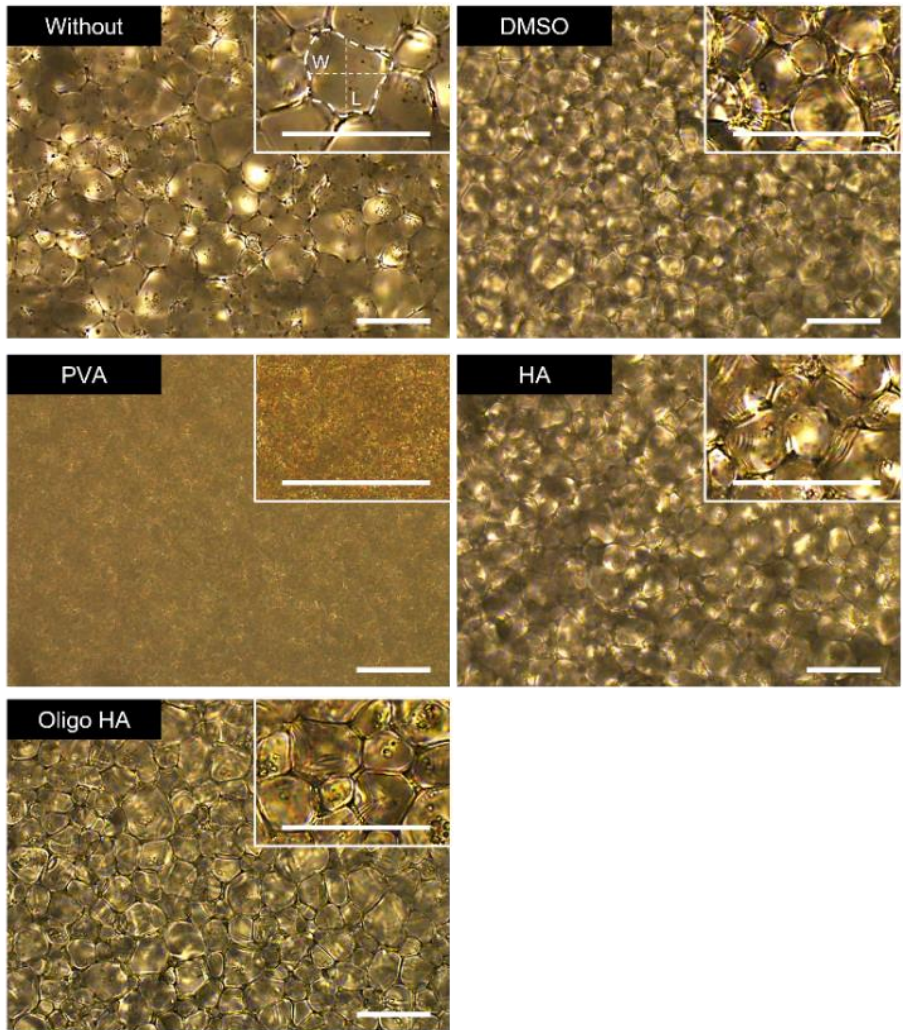

Figure 2. Characterization of ice crystals prepared with cryopreservation media by splat assay. (a) Schematic illustration for the experimental set-up of the splat assay. (b) Photographs showing the ice grains prepared with different cryopreservation media (frozen DMEM (W/O), with 2.5\% DMSO (DMSO) or $10 \mathrm{mg} / \mathrm{mL}$ PVA, HA, or oligo-HA). The samples were annealed at $-8{ }^{\circ} \mathrm{C}$ for $30 \mathrm{~min}$ in a splat-cooling chamber. (Scale bar: $\left.50 \mu \mathrm{m}\right)(\mathrm{c})$ The graph shows the average diameter of ice grains measured from images in Figure 2 a. The data represent the mean \pm S.D. ${ }^{* *} p<0.001$ vs. DMSO. n.s. indicates no significance.

\subsection{Downregulation of RhoA/ROCK1 following Polymer Treatment}

We investigated other mechanisms, apart from that of the ice crystal size reduction, that could increase the effectiveness of cryopreservation. Previous studies have shown that $R h o A$ and ROCK1 signals are important for cell survival during freezing [31,32]. To evaluate whether the polymers modulate the cellular RhoA/ROCK1 signaling pathway, we investigated the expression of RhoA and ROCK1 in NIH-3T3 cells via qRT-PCR and Western blotting. The expression of RhoA and ROCK1 mRNA after treatment with HA or oligo-HA was significantly downregulated in NIH-3T3 cells compared with that in the untreated cells (Figure $3 a, b$ ). Similarly, when tested with HA or oligo-HA, Western blot results showed downregulation of total RhoA and ROCK1 protein in NIH-3T3 cells compared with the untreated cells (Figure $3 c$,d). In contrast, when PVA was treated with NIH-3T3 cells, mRNA and protein expression of RhoA and ROCK1 did not decrease. These results show that HA and oligo-HA decreased the expression of RhoA/ROCK1 in NIH-3T3 cells, implying that the HA-supplemented freezing media contribute to cell cryopreservation through the RhoA/ROCK signaling pathway.

In a recent study, signaling induced by interaction between HA and CD44 receptor of cancer cells was shown to increase protein kinase $C$ and tyrosine kinase activity, thereby lowering oxidative metabolism in the cells $[37,48]$. The complex formed by the HA-CD44 interaction is known to activate cell survival anti-apoptotic proteins, which is similar to our findings in this study [48-51]. This is probably because HA decreases the RhoA/ROCK signaling pathway in cells, thus reducing apoptosis during cryopreservation. These findings provide another perspective for cell cryopreservation using cell-interactive cryoprotectants. In addition, since biopolymers have advantages of high biocompatibility and low 
cytotoxicity compared with petroleum-based synthetic polymers [27,29], cryopreservation medium supplemented with HA and low concentration of DMSO would be beneficial for clinical applications. Since CD44, a receptor for HA in fibroblasts, could regulate collagen accumulation and fibroblast motility [52-54], further studies are needed to investigate the effect of supplemented HAs on cellular functions such as ECM production.
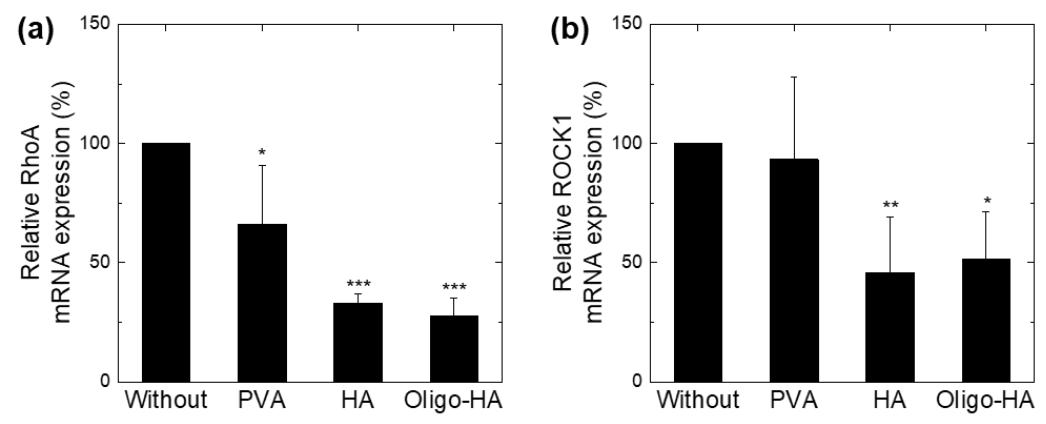

(c)

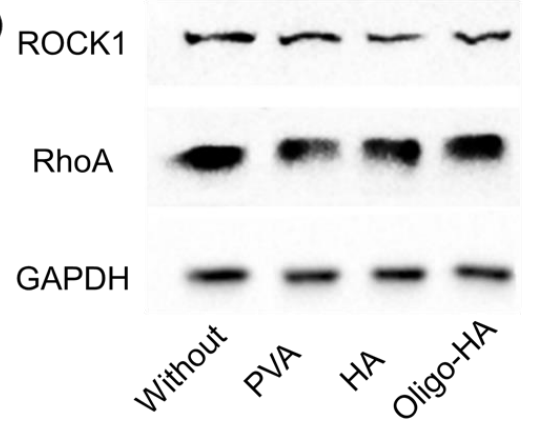

(d)

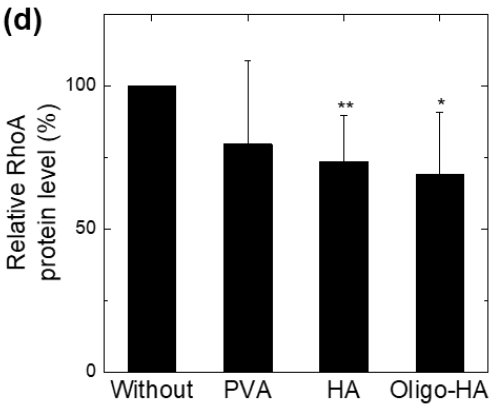

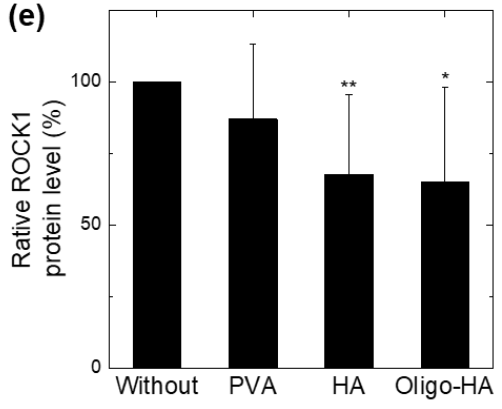

Figure 3. Ras homolog family member A (RhoA)/Rho-associated protein kinase (ROCK) pathway regulation effect of polymeric supplements. NIH-3T3 fibroblast cells were treated with PVA $(10 \mathrm{mg} / \mathrm{mL}), \mathrm{HA}(10 \mathrm{mg} / \mathrm{mL})$, or oligo-HA $(10 \mathrm{mg} / \mathrm{mL})$ for $30 \mathrm{~min}$, and expression levels of RhoA, ROCK1, and glyceraldehyde 3-phosphate dehydrogenase (GAPDH) were determined by quantitative real-time polymerase chain reaction (qRT-PCR) and Western blotting analysis. (a,b) mRNA levels of (a) RhoA and (b) ROCK1 determined through qRT-PCR at 30 min after each treatment with polymers. The mRNA levels were normalized with GAPDH. Data represent mean \pm S.D $(n=5)$. (c) Representative images showing Western blotting data from four independent experiments. (d,e) Bar graphs show Western blot analysis and quantification of (d) RhoA and (e) ROCK1 protein levels. ${ }^{*} p<0.05,{ }^{* *} p<0.01,{ }^{* * *} p<0.001$ vs. without.

\section{Conclusions}

In this study, we report a simple and effective method for reducing the use of DMSO in cryopreservation by using biodegradable hyaluronic acids (HAs). By adding HAs into cryoprotectant media containing a low concentration of DMSO, higher cell viability and cell proliferation rate were observed upon thawing after cryopreservation. When the $\mathrm{HA}$ was added at $1 \mathrm{wt} \%$ to the freezing medium compared with DMSO alone, postthaw recoveries of more than 2-fold were measured. Although HA did not contribute to inhibiting ice recrystallization, it was found that HA was involved in inhibiting RhoA and ROCK signals, thereby reducing apoptosis during cryopreservation. These findings suggest a new cryopreservation method by using a cell-interactive polymeric cryoprotectant with low concentration of DMSO. Since the safety of HA has been proven in the medical field, cryopreservation medium containing HA would be advantageous for clinical translation. However, since this work was performed during a short freezing period at $-80^{\circ} \mathrm{C}$, further studies are needed to confirm the cryopreservation effect of HA on cells after long-term storage in liquid nitrogen. 
Supplementary Materials: The following are available online at https:/ / www.mdpi.com/article/10 .3390/ma14206056/s1, Figure S1: The effect of DMSO concentrations on cell viability, Figure S2: Cell viability after cryopreservation with different cryopreservation media, Figure S3: Cell viability tests using human adipose-derived mesenchymal stem cells and rabbit corneal stromal cells to confirm the cryopreservation effect of HA.

Author Contributions: Conceptualization: T.W.L. and S.Y.Y.; methodology: T.W.L., S.A., G.W.L. and K.-Y.S.; data curation: T.W.L., S.A. and G.W.L.; writing-original draft: T.W.L., G.W.L. and S.Y.Y.; writing-review and editing: T.W.L., J.S.L. and S.Y.Y.; supervision: J.S.L. and S.Y.Y. All authors have read and agreed to the published version of the manuscript.

Funding: This work was supported by Convergence Medical Institute of Technology R\&D project (CMIT2019-06), Pusan National University Hospital.

Institutional Review Board Statement: Not applicable.

Informed Consent Statement: Not applicable.

Data Availability Statement: The data that support the findings of this study are available from the corresponding author upon reasonable request.

Conflicts of Interest: The authors declare that they have no competing interests.

\section{References}

1. Fuggle, N.R.; Cooper, C.; Oreffo, R.O.C.; Price, A.J.; Kaux, J.F.; Maheu, E.; Cutolo, M.; Honvo, G.; Conaghan, P.G.; Berenbaum, F.; et al. Alternative and complementary therapies in osteoarthritis and cartilage repair. Aging Clin. Exp. Res. 2020, 32, 547-560. [CrossRef] [PubMed]

2. Jiang, Z.; Yu, S.; Lin, H.; Bi, R. Expression and function of cartilage-derived pluripotent cells in joint development and repair. Stem Cell Res. Ther. 2020, 11, 111. [CrossRef]

3. Willing, A.E.; Das, M.; Howell, M.; Mohapatra, S.S.; Mohapatra, S. Potential of mesenchymal stem cells alone, or in combination, to treat traumatic brain injury. CNS Neurosci. Ther. 2020, 26, 616-627. [CrossRef] [PubMed]

4. Chu, D.T.; Nguyen, T.T.; Tien, N.L.B.; Tran, D.K.; Jeong, J.H.; Anh, P.G.; Thanh, V.V.; Truong, D.T.; Dinh, T.C. Recent Progress of Stem Cell Therapy in Cancer Treatment: Molecular Mechanisms and Potential Applications. Cells 2020, 9, 563. [CrossRef]

5. Pereira, H.F.; Cengiz, I.F.; Silva, F.S.; Reis, R.L.; Oliveira, J.M. Scaffolds and coatings for bone regeneration. J. Mater. Sci. Mater. Med. 2020, 31, 27. [CrossRef] [PubMed]

6. Serowoky, M.A.; Arata, C.E.; Crump, J.G.; Mariani, F.V. Skeletal stem cells: Insights into maintaining and regenerating the skeleton. Development 2020, 147, dev179325. [CrossRef] [PubMed]

7. Yamakawa, H.; Kusumoto, D.; Hashimoto, H.; Yuasa, S. Stem Cell Aging in Skeletal Muscle Regeneration and Disease. Int. J. Mol. Sci. 2020, 21, 1830. [CrossRef]

8. Mossahebi-Mohammadi, M.; Quan, M.; Zhang, J.S.; Li, X. FGF Signaling Pathway: A Key Regulator of Stem Cell Pluripotency. Front. Cell Dev. Biol. 2020, 8, 79. [CrossRef]

9. Coloma, L.; Cabello, R.; Gonzalez, C.; Quicios, C.; Bueno, G.; Garcia, J.V.; Arribas, A.B.; Clasca, F. Cadaveric Models for Renal Transplant Surgery Education: A Comprehensive Review. Curr. Urol. Rep. 2020, 21, 10. [CrossRef]

10. Tricot, T.; De Boeck, J.; Verfaillie, C. Alternative Cell Sources for Liver Parenchyma Repopulation: Where Do We Stand? Cells 2020, 9, 566. [CrossRef] [PubMed]

11. Zhang, C.; Zhou, Y.; Zhang, L.; Wu, L.; Chen, Y.; Xie, D.; Chen, W. Hydrogel Cryopreservation System: An Effective Method for Cell Storage. Int. J. Mol. Sci. 2018, 19, 3330. [CrossRef] [PubMed]

12. Liu, J.; Zhou, R.; Li, L.; Peters, B.M.; Li, B.; Lin, C.W.; Chuang, T.L.; Chen, D.; Zhao, X.; Xiong, Z.; et al. Viable but non-culturable state and toxin gene expression of enterohemorrhagic Escherichia coli O157 under cryopreservation. Res. Microbiol. 2017, 168, 188-193. [CrossRef]

13. Polge, C.; Smith, A.U.; Parkes, A.S. Revival of spermatozoa after vitrification and dehydration at low temperatures. Nature 1949, 164, 666. [CrossRef]

14. Iussig, B.; Maggiulli, R.; Fabozzi, G.; Bertelle, S.; Vaiarelli, A.; Cimadomo, D.; Ubaldi, F.M.; Rienzi, L. A brief history of oocyte cryopreservation: Arguments and facts. Acta Obstet. Gynecol. Scand. 2019, 98, 550-558. [CrossRef] [PubMed]

15. Lovelock, J.; Bishop, M. Prevention of freezing damage to living cells by dimethyl sulphoxide. Nature 1959, 183, 1394-1395. [CrossRef]

16. Capicciotti, C.J.; Doshi, M.; Ben, R.N. Ice recrystallization inhibitors: From biological antifreezes to small molecules. Recent Dev. Study Recryst. 2013, 177, 224.

17. Ruiz-Delgado, G.J.; Mancias-Guerra, C.; Tamez-Gomez, E.L.; Rodriguez-Romo, L.N.; Lopez-Otero, A.; Hernandez-Arizpe, A.; Gomez-Almaguer, D.; Ruiz-Arguelles, G.J. Dimethyl sulfoxide-induced toxicity in cord blood stem cell transplantation: Report of three cases and review of the literature. Acta Haematol. 2009, 122, 1-5. [CrossRef] 
18. Yong, K.W.; Pingguan-Murphy, B.; Xu, F.; Abas, W.A.; Choi, J.R.; Omar, S.Z.; Azmi, M.A.; Chua, K.H.; Wan Safwani, W.K. Phenotypic and functional characterization of long-term cryopreserved human adipose-derived stem cells. Sci. Rep. 2015, 5, 9596. [CrossRef] [PubMed]

19. Shivakumar, S.B.; Bharti, D.; Subbarao, R.B.; Jang, S.J.; Park, J.S.; Ullah, I.; Park, J.K.; Byun, J.H.; Park, B.W.; Rho, G.J. DMSOand Serum-Free Cryopreservation of Wharton's Jelly Tissue Isolated From Human Umbilical Cord. J. Cell. Biochem. 2016, 117, 2397-2412. [CrossRef]

20. Arutyunyan, I.V.; Strokova, S.O.; Makarov, A.V.; Mullabaeva, S.M.; Elchaninov, A.V.; Lokhonina, A.V.; Abramov, A.A.; Fatkhudinov, T.K. DMSO-Free Cryopreservation of Human Umbilical Cord Tissue. Bull. Exp. Biol. Med. 2018, 166, 155-162. [CrossRef] [PubMed]

21. Hasan, M.; Fayter, A.E.R.; Gibson, M.I. Ice Recrystallization Inhibiting Polymers Enable Glycerol-Free Cryopreservation of Microorganisms. Biomacromolecules 2018, 19, 3371-3376. [CrossRef] [PubMed]

22. Xiang, H.; Yang, X.; Ke, L.; Hu, Y. The properties, biotechnologies, and applications of antifreeze proteins. Int. J. Biol. Macromol. 2020, 153, 661-675. [CrossRef]

23. Elliott, G.D.; Wang, S.; Fuller, B.J. Cryoprotectants: A review of the actions and applications of cryoprotective solutes that modulate cell recovery from ultra-low temperatures. Cryobiology 2017, 76, 74-91. [CrossRef]

24. Robles, V.; Valcarce, D.G.; Riesco, M.F. The Use of Antifreeze Proteins in the Cryopreservation of Gametes and Embryos. Biomolecules 2019, 9, 181. [CrossRef] [PubMed]

25. Biggs, C.I.; Bailey, T.L.; Ben, G.; Stubbs, C.; Fayter, A.; Gibson, M.I. Polymer mimics of biomacromolecular antifreezes. Nature Commun. 2017, 8, 1546. [CrossRef]

26. Bari, J.; Islam, M.; Alam, M.H.; Khatun, A.; Hashem, M.; Moniruzzaman, M. Effect of Polyvinylpyrrolidone on Vitrification of Buffalo (Bubalus bubalis) Oocytes. J. Buffalo Sci. 2020, 9, 152-158. [CrossRef]

27. Li, H.; Li, P.; Yang, Z.; Gao, C.; Fu, L.; Liao, Z.; Zhao, T.; Cao, F.; Chen, W.; Peng, Y.; et al. Meniscal Regenerative Scaffolds Based on Biopolymers and Polymers: Recent Status and Applications. Front. Cell Dev. Biol. 2021, 9, 661802. [CrossRef]

28. Salwowska, N.M.; Bebenek, K.A.; Żądło, D.A.; Wcisło-Dziadecka, D.L. Physiochemical properties and application of hyaluronic acid: A systematic review. J. Cosmet. Dermatol. 2016, 15, 520-526. [CrossRef]

29. Reddy, N.; Reddy, R.; Jiang, Q. Crosslinking biopolymers for biomedical applications. Trends Biotechnol. 2015, 33, 362-369. [CrossRef] [PubMed]

30. Uebersax, L.; Merkle, H.P.; Meinel, L. Biopolymer-based growth factor delivery for tissue repair: From natural concepts to engineered systems. Tissue Eng. Part B Rev. 2009, 15, 263-289. [CrossRef]

31. Tian, J.; Zhang, S.H.; Ma, K.; Zhao, B.Y.; Yan, B.; Pei, C.B.; Zhou, Y.; Wang, H.H.; Wang, H.Y.; Ma, L.H.; et al. Rho/ROCK signaling pathway and anti-cryodamage ability of human sperm. Zhonghua Natl. J. Androl. 2019, 25, 322-328.

32. Gu, M.; Ni, H.; Sheng, X.; Pauciullo, A.; Liu, Y.; Guo, Y. RhoA phosphorylation mediated by Rho/RhoA-associated kinase pathway improves the anti-freezing potentiality of murine hatched and diapaused blastocysts. Sci. Rep. 2017, 7, 6705. [CrossRef] [PubMed]

33. Sebbagh, M.; Renvoizé, C.; Hamelin, J.; Riché, N.; Bertoglio, J.; Bréard, J. Caspase-3-mediated cleavage of ROCK I induces MLC phosphorylation and apoptotic membrane blebbing. Nat. Cell Biol. 2001, 3, 346-352. [CrossRef]

34. Jiang, W.; Li, M.; Chen, Z.; Leong, K.W. Cell-laden microfluidic microgels for tissue regeneration. Lab Chip 2016, 16, 4482-4506. [CrossRef]

35. Lotfi, S.; Mehri, M.; Sharafi, M.; Masoudi, R. Hyaluronic acid improves frozen-thawed sperm quality and fertility potential in rooster. Anim. Reprod. Sci. 2017, 184, 204-210. [CrossRef] [PubMed]

36. Khetan, S.; Corey, O. Maintenance of stem cell viability and differentiation potential following cryopreservation within 3dimensional hyaluronic acid hydrogels. Cryobiology 2019, 90, 83-88. [CrossRef] [PubMed]

37. Fernandez, S.; Cordoba, M. Hyaluronic acid-induced capacitation involves protein kinase C and tyrosine kinase activity modulation with a lower oxidative metabolism in cryopreserved bull sperm. Theriogenology 2018, 122, 68-73. [CrossRef] [PubMed]

38. Sbracia, M.; Grasso, J.; Sayme, N.; Stronk, J.; Huszar, G. Hyaluronic acid substantially increases the retention of motility in cryopreserved/thawed human spermatozoa. Hum. Reprod. 1997, 12, 1949-1954. [CrossRef]

39. Turner, R.A.; Mendel, G.; Wauthier, E.; Barbier, C.; Reid, L.M. Hyaluronan-supplemented buffers preserve adhesion mechanisms facilitating cryopreservation of human hepatic stem/progenitor cells. Cell Transplant. 2012, 21, 2257-2266. [CrossRef]

40. Liu, X.; Pan, Y.; Liu, F.; He, Y.; Zhu, Q.; Liu, Z.; Zhan, X.; Tan, S. A Review of the Material Characteristics, Antifreeze Mechanisms, and Applications of Cryoprotectants (CPAs). J. Nanomater. 2021. [CrossRef]

41. Vail, N.S.; Stubbs, C.; Biggs, C.I.; Gibson, M.I. Ultralow dispersity poly (vinyl alcohol) reveals significant dispersity effects on ice recrystallization inhibition activity. ACS Macro Lett. 2017, 6, 1001-1004. [CrossRef] [PubMed]

42. Bodo, M.; Pezzetti, F.; Baroni, T.; Carinci, F.; Arena, N.; Nicoletti, I.; Becchetti, E. Hyaluronic acid modulates growth, morphology and cytoskeleton in embryonic chick skin fibroblasts. Int. J. Dev. Biol. 2002, 37, 349-352.

43. Harvima, I.T.; Heikura, H.; Hyttinen, M.; Naukkarinen, A. Hyaluronic acid inhibits the adherence and growth of monolayer keratinocytes but does not affect the growth of keratinocyte epithelium. Arch. Dermatol. Res. 2006, 298, 207-219. [CrossRef] [PubMed] 
44. Boeckel, D.G.; Shinkai, R.S.; Grossi, M.L.; Teixeira, E.R. In vitro evaluation of cytotoxicity of hyaluronic acid as an extracellular matrix on OFCOL II cells by the MTT assay. Oral Surg. Oral Med. Oral Pathol. Oral Radiol. 2014, 117, e423-e428. [CrossRef] [PubMed]

45. Fowler, A.; Toner, M. Cryo-injury and biopreservation. Ann. N. Y. Acad. Sci. 2005, 1066, 119-135. [CrossRef] [PubMed]

46. Muldrew, K.; McGann, L.E. Mechanisms of intracellular ice formation. Biophys. J. 1990, 57, 525-532. [CrossRef]

47. Mazur, P. Life in the Frozen State; CRC Press: Boca Raton, FL, USA, 2004; pp. 3-65.

48. Misra, S.; Toole, B.P.; Ghatak, S. Hyaluronan constitutively regulates activation of multiple receptor tyrosine kinases in epithelial and carcinoma cells. J. Biol. Chem. 2006, 281, 34936-34941. [CrossRef] [PubMed]

49. Misra, S.; Ghatak, S.; Toole, B.P. Regulation of MDR1 expression and drug resistance by a positive feedback loop involving hyaluronan, phosphoinositide 3-kinase, and ErbB2. J. Biol. Chem. 2005, 280, 20310-20315. [CrossRef]

50. Misra, S.; Obeid, L.M.; Hannun, Y.A.; Minamisawa, S.; Berger, F.G.; Markwald, R.R.; Toole, B.P.; Ghatak, S. Hyaluronan constitutively regulates activation of COX-2-mediated cell survival activity in intestinal epithelial and colon carcinoma cells. $J$. Biol. Chem. 2008, 283, 14335-14344. [CrossRef]

51. Misra, S.; Hascall, V.C.; Markwald, R.R.; Ghatak, S. Interactions between hyaluronan and its receptors (CD44, RHAMM) regulate the activities of inflammation and cancer. Front. Immunol. 2015, 6, 201. [CrossRef]

52. Razinia, Z.; Castagnino, P.; Xu, T.; Vázquez-Salgado, A.; Puré, E.; Assoian, R.K. Stiffness-dependent motility and proliferation uncoupled by deletion of CD44. Sci. Rep. 2017, 7, 16499. [CrossRef] [PubMed]

53. Acharya, P.S.; Majumdar, S.; Jacob, M.; Hayden, J.; Mrass, P.; Weninger, W.; Assoian, R.K.; Puré, E. Fibroblast migration is mediated by CD44-dependent TGF $\beta$ activation. J. Cell Sci. 2008, 121, 1393-1402. [CrossRef] [PubMed]

54. Govindaraju, P.; Todd, L.; Shetye, S.; Monslow, J.; Puré, E. CD44-dependent inflammation, fibrogenesis, and collagenolysis regulates extracellular matrix remodeling and tensile strength during cutaneous wound healing. Matrix Biol. 2019, 75-76, 314-330. [CrossRef] [PubMed] 